\title{
Pemberdayaan Kelompok Bungong Chirih melalui Produksi Tenun Lidi Nipah
}

\section{(Empowerment of Bungong Chirih Group through Nipah Stick Weaving Production)}

\author{
Adi Bejo Suwardi ${ }^{*}$, Baihaqi², Zidni Ilman Navia ${ }^{3}$, Syardiansah ${ }^{4}$ \\ 1 Program Studi Pendidikan Biologi, Fakultas Keguruan dan Ilmu Pendidikan, Universitas Samudra, \\ Jalan Meurandeh, Meurandeh, Langsa Lama, Kota Langsa, Aceh 24354. \\ 2 Program Studi Pendidikan Bahasa Inggris, Fakultas Keguruan dan Ilmu Pendidikan, Universitas Samudra, \\ Jalan Meurandeh, Meurandeh, Langsa Lama, Kota Langsa, Aceh 24354. \\ 3 Program Studi Biologi, Fakultas Teknik, Universitas Samudra, Jalan Meurandeh, Meurandeh, \\ Langsa Lama, Kota Langsa, Aceh 24354. \\ 4 Program Studi Manajemen, Fakultas Ekonomi, Universitas Samudra, Jalan Meurandeh, Meurandeh, \\ Langsa Lama, Kota Langsa, Aceh 24354. \\ *Penulis Korespondensi: adi.bsw@gmail.com \\ Diterima Agustus 2019/Disetujui Desember 2019
}

\begin{abstract}
ABSTRAK
Kelompok Bungong Chirih merupakan salah satu kelompok kerajinan di Kabupaten Aceh Timur yang telah memproduksi berbagai produk kerajinan tangan. Anggota kelompok kerajinan tersebut mempunyai keterbatasan pengetahuan mengenai produk kerajinan tenun yang bermutu. Selain itu teknologi tenun yang dimiliki juga belum memadai. Tujuan kegiatan ini adalah meningkatkan kemampuan kelompok dalam menghasilkan produk tenun lidi nipah yang beraneka ragam dengan mutu tinggi. Kegiatan dilakukan selama lima bulan mulai dari April-Agustus 2019. Kegiatan pengabdian kepada masyarakat melibatkan 22 orang peserta yang merupakan anggota kelompok Bungong Chirih. Metode pengabdian masyarakat adalah pelibatan anggota kelompok dalam pembelajaran menenun dengan lidi nipah. Kegiatan yang dilakukan meliputi sosialisasi, pelatihan, dan pendampingan. Hasil evaluasi terhadap pelaksanaan kegiatan menunjukkan adanya peningkatan pengetahuan anggota kelompok dalam menghasilkan aneka produk tenun lidi nipah. Hasil kuesioner menunjukkan bahwa sebanyak 20 orang $(90.9 \%)$ peserta memahami dengan baik seluruh materi pelatihan, sedangkan sebanyak dua orang $(9.1 \%)$ cukup memahami seluruh materi pelatihan. Tingkat kepuasan peserta pelatihan menunjukkan bahwa sebanyak 18 orang (81.8\%) merasa sangat puas dan sebanyak empat orang (18.2\%) merasa puas. Kelompok Bungong Chirih telah berhasil memproduksi kotak tisu sebanyak 25 unit, tempat serbet sebanyak 15 unit, kotak minuman kemasan sebanyak 2 unit, map sebanyak 8 unit, sandal hotel sebanyak 6 pasang, tas wanita sebanyak 8 unit, dan vas bunga sebanyak 3 unit. Dari kegiatan yang dilakukan, Kelompok Bungong Chirih mampu membuat rencana pengembangan usaha yang tertuang dalam program kerja tahunan.
\end{abstract}

Kata kunci: alat tenun bukan mesin (ATBM), lidi nipah, pemberdayaan kelompok, tenun

\begin{abstract}
Bungong Chirih group is one of the handicraft women groups in Aceh Timur District which has produced various kinds of handicrafts. The lack of equipment technology facilities and limited member's knowledge were crucial problems in producing high-quality handicraft products. The aim of this activity is to produce highquality nipah stick weaving products. The activity was carried out for five months from April to August 2019. These activities involved 22 participants of Bungong Chirih members group. The mixed methods to develop group capacities in producing quality products were carried out including. group discussions coordination, socialization, training and mentoring. The results of group assessment after the program show that knowledge of the group members on producing various kinds of nipah stick weaving has increased. Twenty group members $(90.9 \%)$ have an excellent understanding of the whole of training materials; two members $(9.1 \%)$ have a moderate understanding of the training material. The $81.8 \%$ group members that participating in the training are very satisfied with the program and $18.2 \%$ are just satisfied. From the mentoring programBungong Chirih women groups are able to produce 25 units of tissue boxes, 15 units of napkins, 2 units of beverage packaging boxes, 8 units of maps, 6 pairs of hotel slippers, 8 units of female bags and 3 units of flower vases. Bungong Chirih women groups are able to develop a business plan that has been cascaded into the group annual work program.
\end{abstract}

Keywords: mechanical (non-machine) weaves instrument, group empowerment, nipah stick, weaving 


\section{PENDAHULUAN}

Desa Matang Gleum menjadi salah satu desa unggulan di Kabupaten Aceh Timur dengan komoditas utama berupa kerajinan tangan. Motif yang berkembang dan turun temurun pada masyarakat Matang Gleum merupakan motif terawang yang dikombinasikan dengan motif anyaman tunggal. Gampong Matang Gleum juga telah ditetapkan sebagai salah satu Kawasan Perdesaan Prioritas Nasional (KPPN) program pengabdian kepada masyarakat DRPM Kemenristekdikti pada tahun 2018. Jumlah penduduk Desa Matang Gleum sebanyak 558 jiwa yang terdiri atas 288 orang laki-laki dan 270 orang perempuan (BPS Kabupaten Aceh Timur 2019).

Kelompok Bungong Chirih merupakan salah satu kelompok usaha kerajinan anyaman tikar pandan di Gampong Matang Gleum yang didirikan sejak tahun 2006 dengan jumlah anggota sebanyak 21 orang. Pada tahun 2016 terdapat penambahan 1 orang anggota baru sehingga jumlah anggota keseluruhan menjadi 22 orang. Anggota kelompok berasal dari tiga dusun, yaitu Dusun Teupin, Ujung Blang, dan Teungoh. Kelompok ini telah memiliki keterampilan dasar menganyam daun pandan (seuke) dan menghasilkan berbagai produk, seperti tikar, kotak tisu, kotak alat tulis, tas sandang, dan sarung bantal.

Teknologi produksi dan pemasaran menjadi permasalahan dalam pengembangan usaha kelompok Bungong Chirih. Kelompok Bungong Chirih masih memproduksi kerajinan secara manual sehingga jumlah dan jenis produk yang dihasilkan masih terbatas. Kelompok Bungong Chirih hanya memproduksi produk berdasarkan pesanan konsumen. Selain itu, kelompok Bungong Chirih masih menggunakan sistem pemasaran secara manual dengan memasarkan produk di pasar tradisional. Usaha produk anyaman tikar daun pandan (seuke) yang sejenis di Gampong Matang Gleum menjadi kompetitor utama dalam pengembangan produk. Tingkat persaingan pasar yang tinggi akibat adanya produk sejenis menyebabkan volume permintaan barang kerajinan tikar pandan pada kelompok Bungong Chirih mengalami penurunan dalam beberapa tahun terakhir.

Hasil diskusi awal antara kelompok Bungong Chirih dengan dosen Universitas Samudra disepakati perlu ada produk kerajinan baru yang lebih inovatif dan belum banyak pesaing. Meskipun demikian, produk kerajinan tangan yang telah ada tetap dikembangkan. Produk tenun lidi nipah disepakati menjadi produk baru yang akan dikembangkan mengingat kondisi kawasan Desa Matang Gleum yang terletak di daerah pesisir memiliki banyak tanaman nipah. Tanaman Nipah banyak ditemukan tumbuh di kebun milik anggota kelompok dengan luas sekitar $5.000 \mathrm{~m}^{2}$. Kontinuitas ketersediaan bahan baku menjadi salah satu faktor penentu keberhasilan dalam pengembangan produk industri (Taib \& Roswita 2018). Meskipun demikian, terbatasnya fasilitas teknologi peralatan dan pengetahuan anggota kelompok dalam pembuatan produk kerajinan tenun dari lidi nipah menjadi kendala yang dihadapi. Tujuan dari kegiatan pengabdian ini adalah menghasilkan produk tenun lidi nipah berkualitas tinggi. Oleh karena itu, dilakukan kegiatan pelatihan dan pendampingan produksi tenun dari lidi nipah bagi kelompok Bungong Chirih, melalui kegiatan ini, diharapkan dapat meningkatkan omset penjualan produk dari kelompok Bungong Chirih sehingga akan terbentuk kelompok produktif dan mandiri.

\section{METODE PELAKSANAAN KEGIATAN}

\section{Waktu dan Tempat}

Kegiatan pendampingan dilakukan bagi kelompok Bungong Chirih Desa Matang Gleum, Kecamatan Peureulak, Kabupaten Aceh Timur (Gambar 1). Kegiatan pelatihan dilaksanakan selama lima bulan mulai dari April-Agustus 2019. Pendampingan dilakukan mulai bulan Agustus-November 2019.

\section{Tahapan dan Metode Pelaksanaan Kegiatan}

Kegiatan pendampingan kelompok Bungong Chirih melibatkan 22 orang anggota kelompok. Kegiatan pelatihan produksi kerajinan tenun lidi nipah untuk Kelompok Usaha Bungong Chirih Desa Matang Gleum, Kecamatan Peureulak, Kabupaten Aceh Timur terdiri atas beberapa tahapan sebagaimana ditunjukkan pada Gambar 2.

\section{- Koordinasi kegiatan}

Kegiatan ini dilakukan dalam rangka menyampaikan rencana pelaksanaan kegiatan untuk kelompok sasaran. Kegiatan koordinasi dilakukan sebanyak 2 (dua) kali. Tim pelaksana PPPUD (Program Pengembangan Produk Unggulan Daerah) dalam pertemuan ini menjelaskan secara detail rincian tahapan kegiatan dan jadwal kegiatan yang akan dilaksanakan. Koordinasi 


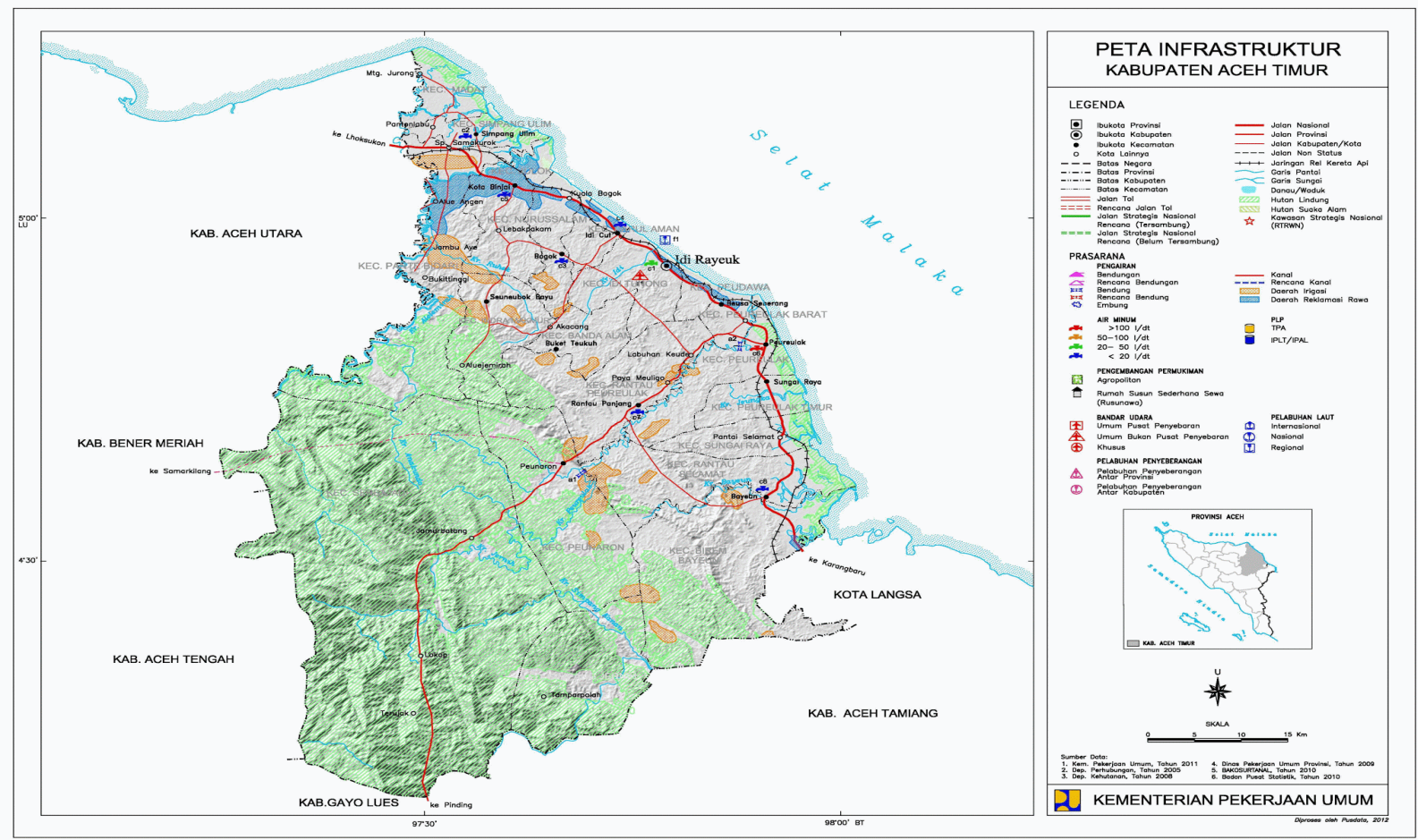

Gambar 1 Lokasi kegiatan pengabdian kepada masyarakat di Desa Matang Gleum.

dilakukan kepada Dinas Pemberdayaan Perempuan, Perlindungan Anak, dan Keluarga Berencana (DP3AKB) Kabupaten Aceh Timur, kepala desa, dan kelompok mitra sasaran.

\section{- Sosialisasi kegiatan}

Sosialisasi merupakan tahap awal dari kegiatan program pengabdian kepada masyarakat yang bertujuan untuk memberikan informasi secara menyeluruh kepada Pemerintah Desa Matang Gleum dan kelompok sasaran tentang rencana kegiatan. Kegiatan ini dilakukan dengan metode diskusi secara langsung. Tim pelaksana PPPUD memaparkan tahapan kegiatan, peserta kegiatan, dan target yang akan dicapai. Kegiatan sosialisasi dihadiri oleh 38 orang yang terdiri atas kepala Dinas Pemberdayaan Masyarakat Gampong (DPMG) Kabupaten Aceh Timur, kepala Dinas Pemberdayaan Perempuan, Perlindungan Anak, dan Keluarga Berencana (DP3AKB) Kabupaten Aceh Timur, Kepala Bidang Pemberdayaan dan Partisipasi Perempuan DP3AKB Kabupaten Aceh Timur, Camat Peureulak, tokoh masyarakat dan seluruh anggota kelompok Bungong Chirih. Tindak lanjut dari kegiatan sosialisasi ini berupa kesepakatan waktu pelaksanaan kegiatan dan target yang harus dicapai di akhir kegiatan.

\section{- Kegiatan pelatihan}

Kegiatan pelatihan menggunakan model pendekatan Participatory Rural Appraisal (PRA) yang

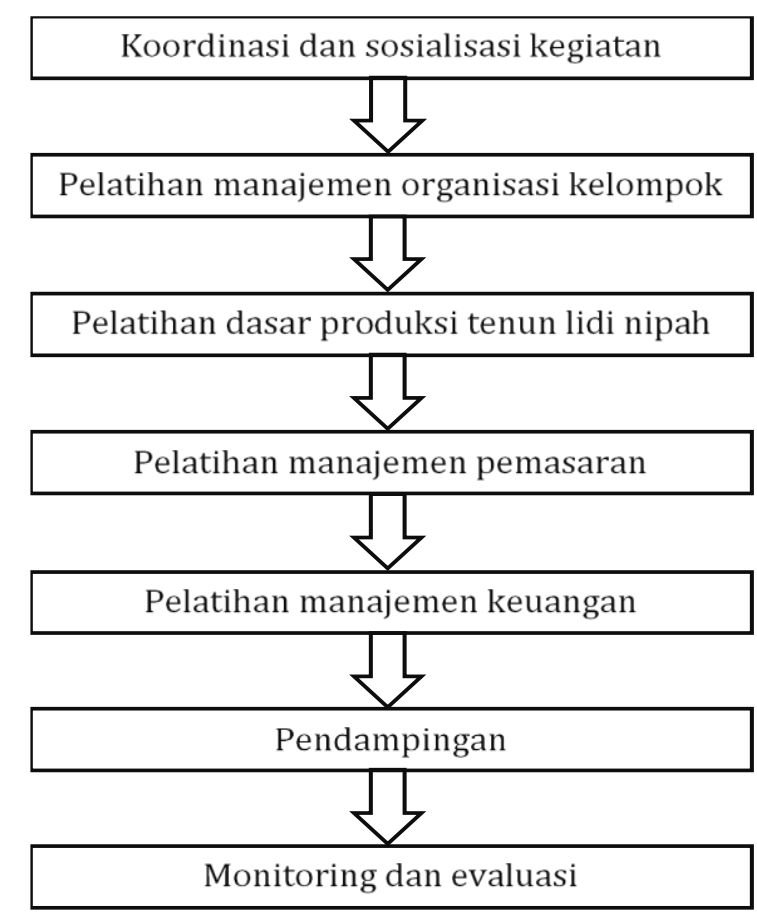

Gambar 2 Tahapan kegiatan pendampingan kelompok Bungong Chirih.

menekankan keterlibatan masyarakat dalam keseluruhan kegiatan mulai dari perencanaan, pelaksanaan, dan evaluasi program kegiatan. Kegiatan pelatihan terdiri dari empat jenis kegiatan, yaitu pertama kegiatan pelatihan manajemen organisasi kelompok. Pelatihan manajemen organisasi kelompok bertujuan untuk memberikan pemahaman kepada peserta pentingnya mengembangkan usaha secara 
berkelompok. Peserta pelatihan diharapkan mampu mengelola organisasi kelompok yang sudah terbentuk dengan baik dan benar, peserta mampu mengelola administrasi organisasi maupun organisasi keuangan yang transparan, peserta memiliki kemampuan dalam penggalian modal usaha dan pendayagunaannya, serta dapat memahami cara membangun jaringan kerja dan peran kelompok di tengah masyarakat. Peserta diberikan beberapa materi dalam pelatihan ini, di antaranya materi tentang pengertian, prinsipprinsip, tujuan, pembagian tugas dan pekerjaan, wewenang dan tanggung jawab, struktur, dan model-model organisasi.

Kedua, pelatihan produksi tenun lidi nipah yang terdiri atas dua kegiatan, yaitu pelatihan tenun lidi nipah dan pewarnaan. Pelatihan tenun lidi nipah dilakukan selama 7 hari dan dipandu oleh trainer dari Provinsi Yogyakarta. Pelatihan tenun lidi nipah terdiri atas beberapa tahapan, yaitu perakitan dan teknik penggunaan ATBM (alat tenun bukan mesin) teknik dasar menenun, dan teknik desain motif tenun. Setelah diberikan materi pelatihan, peserta diberikan kesempatan praktik langsung untuk menghasilkan produk tenun lidi nipah. Pelatihan pewarnaan produk dilakukan selama 1 hari. Pelatihan pewarnaan produk meliputi kegiatan pelatihan peracikan bahan warna, pewarnaan, dan kombinasi warna. Ketiga, pelatihan manajemen pemasaran, yang bertujuan untuk memberikan pengetahuan secara mendasar tentang strategi pemasaran dan teknik mengaplikasikannya. Pelatihan manajemen pemasaran berisi teknik membuat kemasan, label, dan merek yang lebih menarik minat konsumen, penentuan harga produk, dan strategi pemasaran produk. Kegiatan ini dilaksanakan selama 3 hari. Keempat, pelatihan manajemen keuangan yang bertujuan untuk memberikan pengetahuan kepada kelompok tentang pengelolaan administrasi dan keuangan. Kegiatan ini dilakukan selama 2 hari. Materi yang diberikan berupa teknik pembukuan dan pengelolaan keuangan kelompok.

\section{- Pendampingan}

Pendampingan dilakukan setelah kegiatan pelatihan selesai dilaksanakan. Metode pendampingan yang diterapkan berupa metode konsultasi. Konsultasi adalah upaya pembantuan yang diberikan pendamping terhadap masyarakat dengan cara memberikan jawaban, solusi, dan pemecahan masalah yang dibutuhkan oleh masyarakat. Kegiatan pendampingan berisi diskusi terkait permasalahan yang dihadapi oleh kelompok Bungong Chirih dalam mengaplikasikan hasil pelatihan serta mencari pemecahan permasalahan secara bersama-sama.

\section{- Monitoring dan evaluasi}

Monitoring dilakukan terhadap seluruh rangkaian kegiatan pelatihan. Secara umum dikenal dua tipe evaluasi, yaitu on going evaluation atau evaluasi terus menerus dan ex post evaluation atau evaluasi akhir (Hadiyanti 2008). Pada kegiatan pengabdian ini, proses evaluasi dilakukan pada akhir program (ex post evaluation). Menurut Hadiyanti (2008), evaluasi kegiatan pemberdayaan masyarakat bertujuan untuk mengidentifikasi tingkat pencapaian tujuan, mengukur dampak langsung yang terjadi pada kelompok sasaran, serta mengetahui dan menganalisis konsekuensi-konsekuensi lain yang mungkin terjadi di luar rencana. Pada kegiatan pengabdian ini, evaluasi dilakukan terhadap tingkat pencapaian tujuan program, tingkat pengetahuan peserta, tingkat kepuasan peserta, dan dampak langsung yang terjadi pada kelompok sasaran. Tingkat pengetahuan dan kepuasan peserta diukur dengan menggunakan angket dengan skala likert 1-5 (1 = sangat kurang; 2 = kurang; 3 = cukup; 4 = baik; dan $5=$ sangat baik). Beberapa pertanyaan dalam kuesioner evaluasi pelatihan antara lain: a) Pelatihan yang diselenggarakan memiliki sasaran yang jelas dan bermanfaat; b) Kesesuaian materi pelatihan dengan yang diharapkan; c) Pemahaman dan penguasaan materi dari instruktur; d) Kemampuan instruktur memahami dan menjawab pertanyaan; e) Bimbingan yang diberikan instruktur dalam pelatihan mudah dimengerti; f) Materi yang disampaikan mampu menambah pengetahuan peserta pelatihan; dan g) Materi yang diberikan mampu memotivasi peserta pelatihan

\section{HASIL DAN PEMBAHASAN}

\section{Kegiatan Sosialisasi Pengabdian kepada Masyarakat}

Kegiatan sosialisasi dilakukan kepada Pemerintah Kampung Paya Bedi dan kelompok sasaran yang dipusatkan di balai produksi kelompok Bungong Chirih Desa Matang Gleum pada tanggal 3 Mei 2019. Dalam kegiatan ini, tim dosen Universitas Samudra memberikan penjelasan secara mendetail tentang urutan dan jadwal kegiatan pendampingan terhadap kelompok Bungong Chirih yang direncanakan 
dilakukan selama 6 bulan. Pemerintah Desa Matang Gleum mendukung pelaksanaan kegiatan tersebut. Bentuk dukungan pemerintah desa berupa renovasi balai kerja dan memfasilitasi pemasaran produk kelompok Bungong Chirih melalui pameran-pameran dan Badan Usaha Milik Gampong. Dalam kegiatan ini, juga turut hadir utusan dari pemerintah daerah Kabupaten Aceh Timur yang diwakili oleh kepala Dinas Pemberdayaan Masyarakat Gampong (DPMG) Kabupaten Aceh Timur, kepala Dinas Pemberdayaan Perempuan, Perlindungan Anak, dan Keluarga Berencana (DP3AKB) Kabupaten Aceh Timur, Kepala Bidang Pemberdayaan dan Partisipasi Perempuan DP3AKB Kabupaten Aceh Timur, Camat Peureulak, dan tokoh masyarakat. Respon peserta sosialisasi sangat baik. Kelompok Bungong Chirih bersedia mengikuti seluruh tahapan pelatihan. Pemerintah Kabupaten Aceh Timur juga memberikan respons positif terkait kegiatan ini dan bersedia untuk memfasilitasi pemasaran produk tenun lidi nipah sebagai salah satu produk unggulan daerah di Kabupaten Aceh Timur.

\section{Kegiatan Pelatihan Manajemen Organisasi Kelompok}

Kegiatan pelatihan menajemen organisasi kelompok dilakukan selama tiga hari pada tanggal 21-23 Juni 2019 bertempat di balai kerja kelompok Bungong Chirih. Kegiatan ini diikuti sebanyak 22 orang peserta. Kegiatan pelatihan manajemen organisasi dipilih berdasarkan hasil assessment awal yang menemukan bahwa secara administrasi, kepemimpinan, dan komunikasi dalam kelompok masih terbatas. Pelatihan manajemen organisasi kelompok ini penting karena dapat meningkatkan kerja sama dalam kelompok, membentuk emotional intelegent, memudahkan dalam pembagian kerja, memudahkan dalam penentuan dan pencapaian target kerja, dan memudahkan dalam perencanaan bisnis. Materi yang diberikan kepada peserta pada kegiatan ini adalah pemahaman tentang konsep dasar berkelompok, struktur organisasi dan pembagian tugas, administrasi organisasi, kerja sama tim, perencanaan bisnis dan strategi komunikasi dalam kelompok. Gambar 3 menunjukkan pelatihan manajemen organisasi kelompok.

Kegiatan diawali dengan kontrak belajar yang berisi komitmen dan aturan bagi peserta pelatihan dalam mengikuti rangkaian kegiatan pelatihan. Kontrak belajar penting sebagai upaya untuk menumbuhkan rasa kepemilikan dan korsa peserta terhadap pelatihan sehingga peserta aktif dan bebas mengemukakan pendapatnya untuk menentukan jadwal, peraturan pelatihan, dan kompetensi yang akan dicapai oleh peserta selama progam pelatihan berlangsung (Mujiman 2007; UNDP 2012). Model pembelajaran yang digunakan berupa model pembelajaran orang dewasa. Pola pemberdayaan masyarakat usia kerja yang efektif dapat dilakukan dengan menerapkan prinsip-prinsip belajar orang dewasa (Rai 2013).

Kegiatan ini telah menghasilkan Anggaran Dasar dan Anggaran Rumah Tangga (AD/ART) kelompok Bungong Chirih, struktur organisasi baru yang terdiri atas ketua, sekretaris, bendahara, bagian produksi, dan bagian pemasaran. Kelompok Bungong Chirih juga telah membuat dokumen pengajuan legalitas usaha dalam bentuk Izin Usaha Mikro Kecil (IUMK) yang telah diajukan ke pihak Kecamatan Peureulak. Kegiatan pelatihan berjalan dengan lancar dan seluruh peserta kegiatan sangat antusias terhadap materi yang diberikan. Hasil evaluasi di akhir kegiatan pelatihan dengan menggunakan angket menunjukkan bahwa 5 orang peserta $(22,7 \%)$ sangat memahami materi pelatihan, 15 orang $(68,2 \%)$ memahami, dan 2 orang $(9,1 \%)$ cukup memahami materi pelatihan. Secara umum anggota kelompok memahami bahwa untuk mencapai suatu tujuan diperlukan sebuah wadah berupa organisasi kelompok yang memiliki legalitas dan didukung oleh semua anggota kelompok, sehingga terbentuk kelompok produktif.

\section{Kegiatan Pelatihan Produksi Tenun Lidi Nipah dengan Menggunakan ATBM}

Kegiatan pelatihan produksi tenun lidi nipah dilakukan selama 8 hari pada tanggal 7-14 Juli 2019 bertempat di balai kerja kelompok Bungong Chirih. Kegiatan ini diikuti oleh 22 orang peserta.

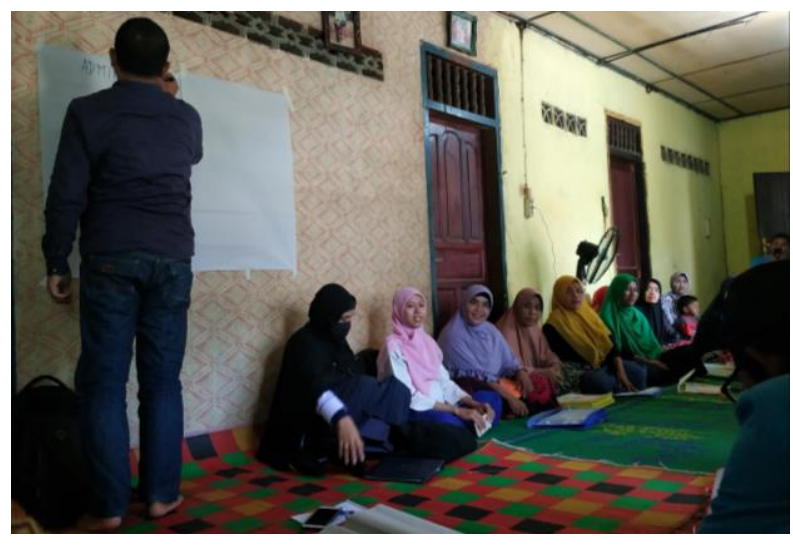

Gambar 3 Pelatihan manajemen organisasi kelompok. 
Kegiatan pelatihan berisi materi tentang prospek tenun lidi nipah, teknik perakitan alat tenun bukan mesin (ATBM), teknik pengoperasian ATBM, teknik dasar menenun, teknik pewarnaan lidi nipah, dasar-dasar pembuatan pola produk, dan pembuatan produk.

Pelatihan hari pertama berupa perakitan ATBM yang diikuti sebanyak 22 orang peserta dari kelompok Bungong Chirih dan dipandu oleh instruktur dari Yogyakarta. ATBM adalah satu alat yang digunakan untuk menenun tanpa menggunakan tenaga mesin melainkan peralatan kayu yang tradisional. Instruktur menjelaskan secara detail tentang teknik pemintalan benang, pemasangan benang, dan penggunaan ATBM dalam menghasilkan produk tenun berkualitas tinggi.

Pelatihan teknik dasar menenun dilakukan pada hari kedua (Gambar 4a). Trainer memberikan penjelasan tentang dasar-dasar menenun dengan menggunakan ATBM. Teknik tenun hampir sama dengan teknik anyaman, perbedaannya terletak pada alat yang digunakan. Teknik tenun menggunakan alat tenun yang disebut lungsi dan pakan, sedangkan teknik anyam hanya menggunakan tangan (Suwardi et al. 2018). Pada pelatihan ini, instruktur juga menjelaskan tentang tata cara memasukkan benang pada ATBM. Benang yang ditenun berukuran $3 \mathrm{~mm}$ dimana bagian tengah benang dimasukkan ke ujung lidi nipah secara ber-
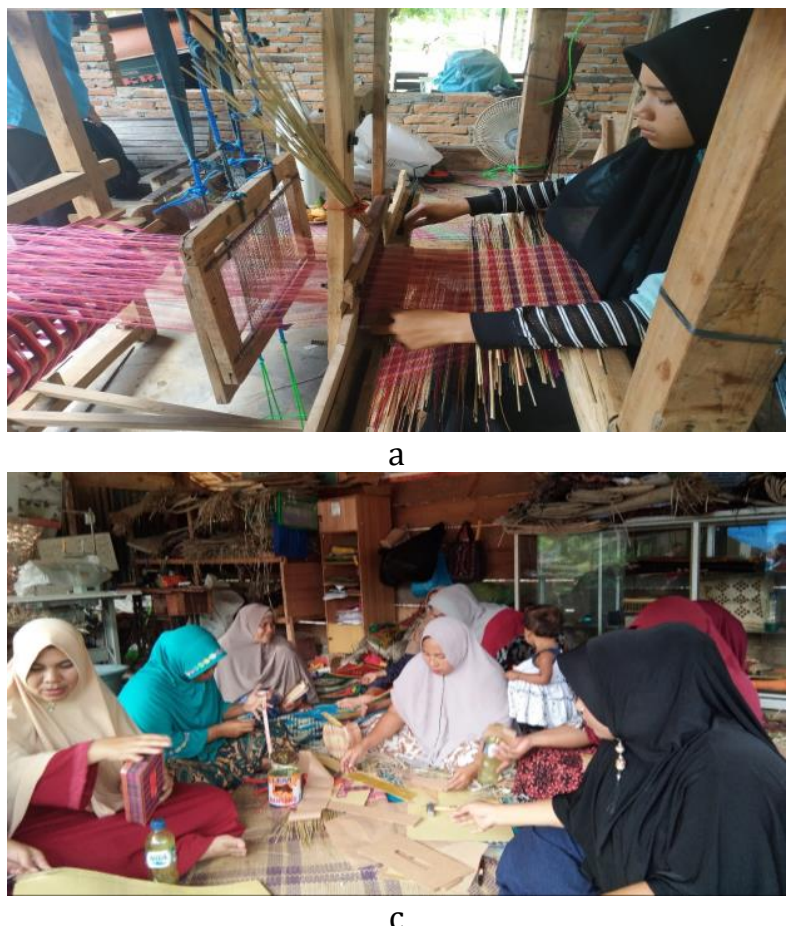

samaan pada alat tenun tersebut sesuai dengan motif hias yang akan dibuat. Benang tenun dipersilangkan tegak lurus membentuk sudut $90^{\circ}$ (Poespo 2005). Setiap peserta diberikan kesempatan untuk menenun lidi nipah menggunakan ATBM.

Pelatihan hari ketiga diisi dengan pembuatan pola dan motif untuk produk kerajinan tenun (Gambar 4b). Motif adalah pekerjaan menyusun, merangkai, dan memadukan bentuk-bentuk dasar suatu bentuk seperti garis dan sebagainya sedemikian rupa kemudian dilakukan pengulangan sehingga tercipta bentuk gambar baru yang indah, bernilai seni, serta original (Soehersono 2010). Setiap orang dibimbing untuk menghasilkan pola dan motif tenun yang akan dibuat menjadi aneka produk kerajinan tenun.

Pelatihan hari keempat sampai ketujuh memfokuskan pada pembuatan aneka produk kerajinan tenun dari lidi nipah dengan menggunakan ATBM (Gambar 4c). Dalam pelatihan ini, setiap peserta diharuskan menghasilkan satu produk tenun lidi nipah yang menarik dan berpotensi untuk dipasarkan. Peserta pelatihan didampingi oleh instruktur dan tim dosen dari Universitas Samudra dalam menghasilkan produk tenun.

Pelatihan hari kedelapan berupa teknik pewarnaan lidi nipah (Gambar 4d). Peserta diberikan pemahaman tentang teknik meng-

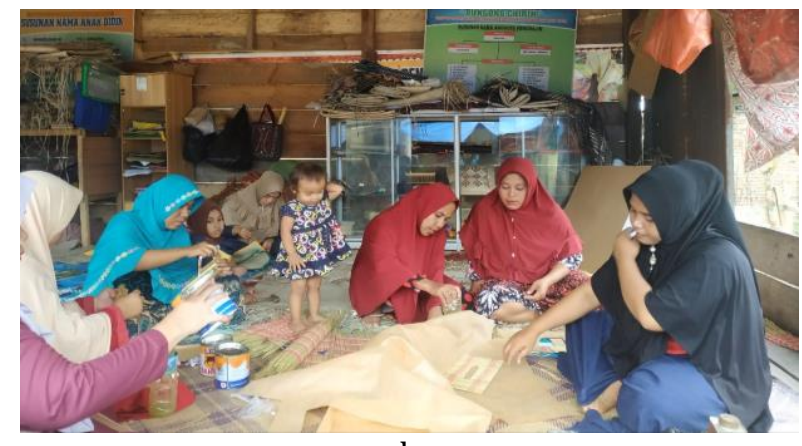

b

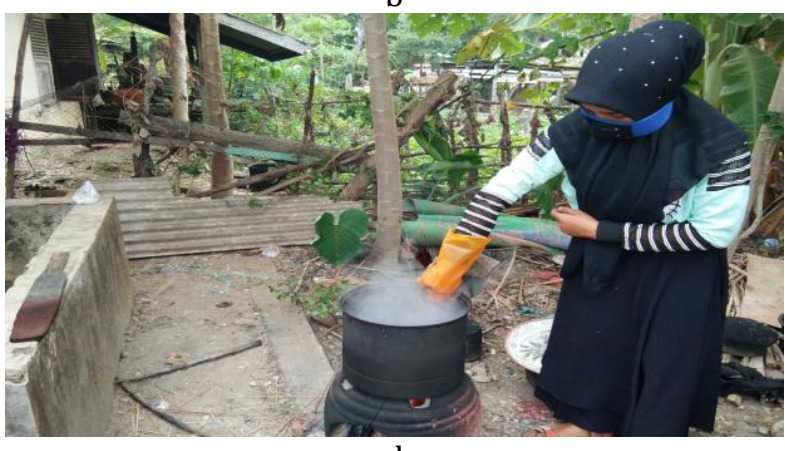

d

Gambar 4 Pelatihan produksi tenun lidi nipah: a) Teknik dasar menenun; b) Pembuatan pola dan motif produk; c) Pembuatan produk; dan d) Teknik pewarnaan. 
kombinasikan warna dasar (merah, biru, dan kuning) menjadi berbagai macam warna. Peserta diberikan materi terkait teknik pewarnaan lidi nipah. Selain itu, peserta juga diberikan pemahaman terkait pentingnya keamanan, kesehatan dan keselamatan kerja (K3). K3 adalah suatu program untuk mencegah timbulnya kecelakaan dan penyakit akibat kerja dengan cara mengenali hal-hal yang berpotensi menimbulkan kecelakaan dan penyakit akibat kerja serta tindakan antisipatif apabila terjadi kecelakaan dan penyakit akibat kerja (Tyas 2011). Kegiatan ini diberikan karena dalam proses pewarnaan, peserta menggunakan pewarna tekstil. Selain itu, untuk mencegah terjadinya pencemaran lingkungan, limbah dari proses pewarnaan dibuang pada IPAL (instalasi pengolahan air limbah) sederhana yang telah dibuat oleh tim dosen Universitas Samudra.

Kegiatan ini telah menghasilkan berbagai produk kerajinan tenun lidi nipah seperti kotak tisu, tempat serbet, kotak minuman kemasan, map, sandal, tas wanita, dan vas bunga (Gambar 5). Hasil evaluasi di akhir kegiatan pelatihan melalui observasi langsung menunjukkan bahwa seluruh peserta $(100 \%)$ telah memahami teknik menenun lidi nipah. Sebelum pelatihan dilaksanakan belum ada peserta yang pernah mengoperasikan alat tenun. Peserta diperkenalkan alat tenun serta teknik mengoperasikannya melalui pelatihan ini, sehingga peserta telah mampu menghasilkan berbagai produk kerajinan tenun dari lidi nipah.

\section{Kegiatan Pelatihan Manajemen Pemasaran}

Kegiatan pelatihan manajemen pemasaran dilaksanakan selama tiga hari, yaitu pada tanggal 25-27 Juli 2019. Pelatihan manajemen pemasaran berisi teknik membuat kemasan, label, dan merek yang lebih menarik minat konsumen, penentuan harga produk, serta strategi pemasaran produk (Gambar 6). Inti dari masingmasing materi manajemen pemasaran yaitu pelatihan marketing mix dalam mengelola pemasaran produk. Dari sisi produk, dimana produk yang dihasilkan harus mampu menarik konsumen dalam bentuk fisik, warna dan bahan baku yang digunakan. Dari sisi harga, harga jual yang ditawarkan harus mampu bersaing dengan produk sejenis namun tetap mempertahankan mutu produk. Dari sisi tempat, setiap produk yg dijual harus memperhatian lokasi penjualannya sehingga mudah dijangkau oleh konsumen. Dari sisi promosi, perlu memperhatikan perkembangan zaman dengan memanfaatkan teknologi, informasi dan komunikasi. Kegiatan ini telah menghasilkan merek dagang produk yaitu "Bungong Chirih", katalog produk, serta media pemasaran berupa banner dan media sosial (facebook dan instagram Bungong Chirih). Anggota kelompok Bungong Chirih juga telah memiliki kemampuan dalam menentukan harga pokok produk dan harga jual produk.

\section{Pelatihan Manajemen Keuangan}

Kegiatan pelatihan manajemen keuangan dilaksanakan selama dua hari, yaitu pada tanggal 3-4 Agustus 2019. Pelatihan manajemen keuangan berisi teknik pembukuan dan pengelolaan keuangan kelompok (Gambar 7). Kegiatan ini telah menghasilkan buku kas kelompok dan software pembukuan. Anggota kelompok juga telah sepakat untuk membuat iuran bulanan sebagai modal pengembangan usaha. Kegiatan pelatihan berjalan dengan baik dan diikuti oleh seluruh anggota kelompok. Hasil evaluasi di akhir kegiatan pelatihan dengan menggunakan angket menunjukkan bahwa sebanyak 4 orang peserta $(18,2 \%)$ sangat memahami materi pelatihan, 6 orang $(27,3 \%)$ memahami, dan 8 orang $(54,5 \%)$ cukup memahami materi pelatihan. Faktor usia dan tingkat pendidikan menjadi faktor penyebab bagi beberapa orang anggota dalam memahami materi pelatihan terutama dalam pembukuan. Meskipun demikian, ketua dan bendahara kelompok telah memahami dengan baik terkait pembukuan dan pengelolaan keuangan kelompok.

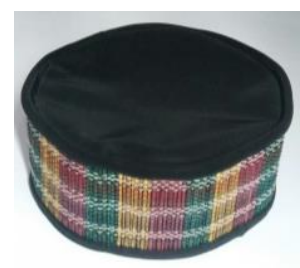

a

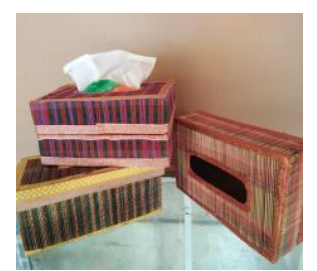

b

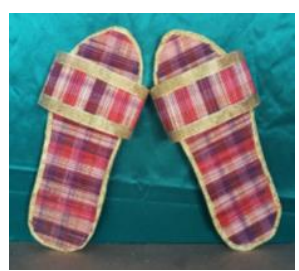

C

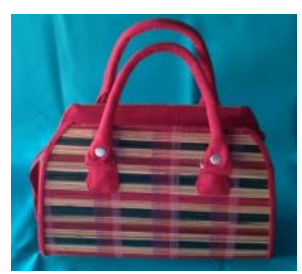

d

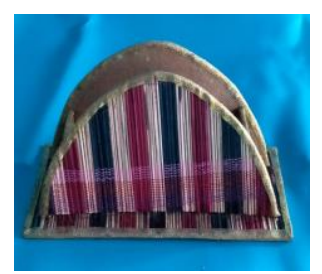

e

Gambar 5 Produk tenun lidi nipah: a) Tempat minuman kemasan; b) Tempat tisu; c) Sandal hotel; d) Tas wanita; dan e) Tempat serbet. 


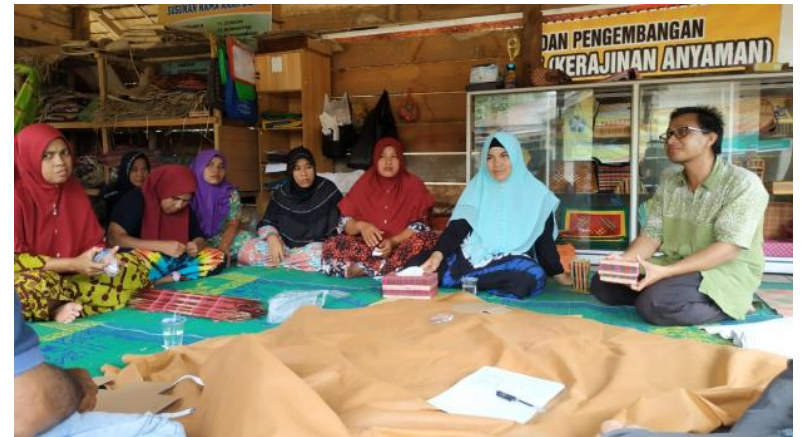

Gambar 6 Pelatihan manajemen pemasaran.

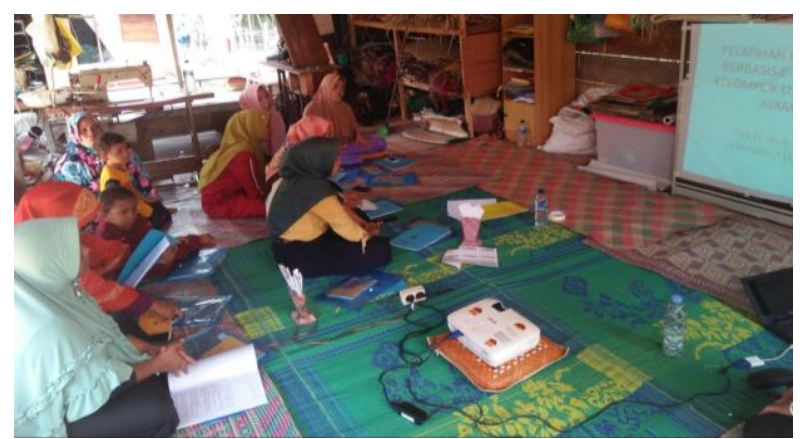

Gambar 7 Pelatihan manajemen keuangan.

\section{Kegiatan Pemeran Produk Tenun Lidi Nipah}

Upaya untuk pengenalan dan peningkatan penjualan produk, kelompok Bungong Chirih mengikuti pemeran produk pada kegiatan Bursa Inovasi Kecamatan pada tahun 2019 yang diselenggarakan oleh pihak Kecamatan Peureulak pada tanggal 24 Juli 2019. Promosi ini penting dilakukan untuk meningkatkan penjualan produk (Ahyuna et al. 2013; Unonongo et al. 2015). Kelompok Bungong Chirih ditunjuk secara khusus oleh Kepala Desa Matang Gleum sebagai perwakilan Desa Matang Gleum dalam kegiatan tersebut.

Produk tenun lidi nipah yang ditampilkan dalam Bursa Inovasi Desa mendapat perhatian dan apresiasi dari pengunjung. Gambar 8 menunjukkan pameran produk tenun lidi nipah pada Bursa Inovasi Kecamatan. Kepala dinas DPMG provinsi Aceh sangat tertarik dengan ATBM dan produk tenun lidi nipah yang dihasilkan kelompok Bungong Chirih. Selain itu, turut hadir pula kepala dinas DPMG Kabupaten Aceh Timur dan Camat Peureulak yang turut mendampingi kepala dinas DPMG Provinsi Aceh. Menurut Kepala Dinas DPMG Kabupaten Aceh Timur, produk tenun lidi nipah merupakan produk yang baru ada di Kabupaten Aceh Timur. Beliau memberikan apresiasi yang luar biasa kepada tim dosen Universitas Samudra yang telah memberikan pendampingan produksi tenun lidi nipah kepada kelompok Bungong

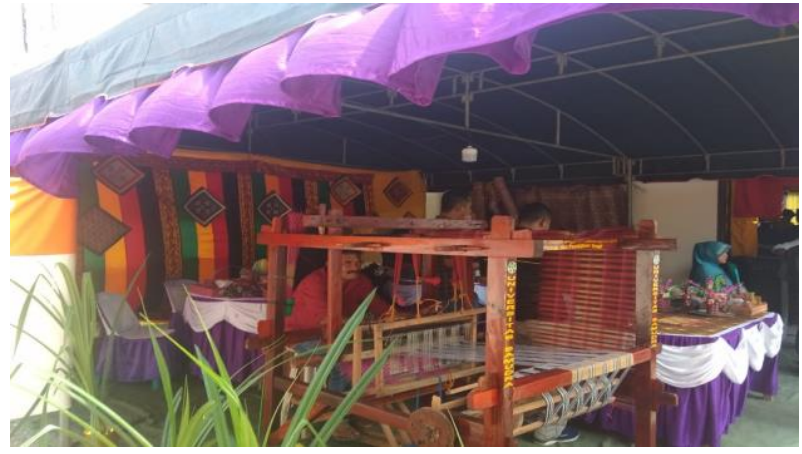

Gambar 8 Pameran produk tenun lidi nipah pada bursa inovasi kecamatan.

Chirih. Pemerintah Kabupaten Aceh Timur akan mendorong dan memfasilitasi pengembangan produk tenun lidi nipah menjadi salah satu produk unggulan di Kabupaten Aceh Timur.

\section{Monitoring dan Evaluasi}

Hasil monitoring terhadap pelaksanaan kegiatan menunjukkan adanya peningkatan pengetahuan anggota kelompok dalam menghasilkan aneka produk tenun. Hasil angket/ kuesioner menunjukkan bahwa sebanyak 20 orang $(90,9 \%)$ peserta memahami dengan baik seluruh materi pelatihan, sedangkan sebanyak 2 orang $(9,1 \%)$ cukup memahami seluruh materi pelatihan. Melalui diskusi dan penerapan hasil pelatihan terlihat bahwa anggota kelompok telah memahami pentingnya berorganisasi, telah mampu membuat perencanaan usaha, mampu membuat produk tenun, mampu menentukan harga dasar produk, dan mampu membuat pembukuan usaha. Tingkat kepuasan peserta pelatihan menunjukkan bahwa sebanyak 18 orang $(81,8 \%)$ merasa sangat puas dan sebanyak 4 orang $(18,2 \%)$ merasa puas. Peserta merasa puas karena seluruh materi pelatihan yang diberikan mudah dipahami dan disertai dengan praktik langsung sehingga meningkatkan pemahaman dan keterampilan peserta. Secara umum, pelaksanaan kegiatan pengabdian kepada masyarakat tidak mengalami kendala. Anggota kelompok mitra mengikuti seluruh rangkaian kegiatan dengan antusias. Hal ini disebabkan karena produk tenun lidi nipah merupakan produk yang baru mereka kenal dan berpotensi untuk dikembangkan. Program ini memberikan dampak yang signifikan terhadap peningkatan omset kelompok. Pascapelatihan (periode September-November 2019), kelompok telah berhasil memproduksi sebanyak 13 jenis produk dengan jumlah total sebanyak 850 unit. Produk yang mampu dipasarkan sebanyak 682 unit $(80,23 \%)$ dengan omset mencapai Rp. 
66.790.000. Peningkatan omset usaha kelompok juga berdampak pada peningkatan penghasilan anggota kelompok.

\section{Rencana Keberlanjutan Program}

Kelompok Bungong Chirih telah membuat rencana pengembangan usaha yang tertuang dalam program kerja tahunan. Tim dosen Universitas Samudra juga berencana akan mendampingi selama dua tahun ke depan melalui program Pengembangan Produk Unggulan Daerah melalui pendanaan DRPM Kemenristekdikti. Program pendampingan akan difokuskan pada penguatan stok produk, pemasaran, dan penguatan jaringan bisnis. Pengurus kelompok Bungong Chirih bersama anggota telah berkomitmen untuk mengembangkan usaha melalui peningkatan produksi dan pemasaran, penguatan modal usaha melalui dukungan pendanaan dari Badan Usaha Milik Gampong (BUMG). Selain itu, kelompok Bungong Chirih juga berkomitmen untuk tetap melanjutkan produksi tenun lidi nipah meskipun program PPPUD telah berakhir.

\section{SIMPULAN}

Kelompok Bungong Chirih telah mampu memproduksi aneka produk kerajinan tenun dari lidi nipah. Kelompok Bungong Chirih telah berhasil memproduksi memproduksi sebanyak 13 jenis produk dengan jumlah total sebanyak 850 unit. Produk yang mampu dipasarkan sebanyak 682 unit $(80,23 \%)$ dengan omset mencapai Rp. 66.790.000. Hasil evaluasi terhadap pelaksanaan kegiatan menunjukkan adanya peningkatan pengetahuan anggota kelompok dalam menghasilkan aneka produk tenun lidi nipah. Hasil kuesioner menunjukkan bahwa 20 orang $(90,9 \%)$ peserta memahami dengan baik seluruh materi pelatihan, sedangkan 2 orang $(9,1 \%)$ cukup memahami seluruh materi pelatihan. Tingkat kepuasan peserta pelatihan menunjukkan bahwa 18 orang $(81,8 \%)$ merasa sangat puas dan 4 orang $(18,2 \%)$ merasa puas. Kelompok Bungong Chirih telah membuat rencana pengembangan usaha yang tertuang dalam program kerja tahunan. Program pengabdian kepada masyarakat memiliki dampak yang signifikan dalam meningkatkan omset kelompok.

Rekomendasi dari pelaksanaan program ini antara lain: 1) Perlu dilakukan sinergisitas antara UKM, pemerintah desa, pemerintah daerah dan perguruan tinggi dalam pelaksanaan kegiatan pengabdian kepada masyarakat; 2) Perlu adanya dukungan penyertaan modal usaha dari desa untuk mendukung pengembangan produk usaha Bungong Chirih; 3) Perlu adanya kebijakan kemudahan dalam pengurusan perizinan dan pendaftaran merek dagang produk UMKM; dan 4) Perlu ada kebijakan penggunaaan produk lokal hasil produksi UMKM dalam setiap pelaksanaan kegiatan seperti seminar, rapat, dan lainnya yang diselenggarakan oleh dinas-dinas di wilayah Kabupaten Aceh Timur.

\section{UCAPAN TERIMA KASIH}

Penulis mengucapkan terima kasih kepada Direktorat Riset dan Pengabdian kepada Masyarakat, Kementerian Riset, Teknologi, dan Pendidikan Tinggi RI yang telah mendanai kegiatan pengabdian kepada masyarakat melalui skema Program Pengembangan Produk Unggulan Daerah (PPPUD) tahun 2019. Penulis juga mengucapkan terima kasih kepada Rektor Universitas Samudra, Pemerintah Kabupaten Aceh Timur, Pemerintah Desa Matang Gleum, dosen dan mahasiswa Universitas Samudra, serta masyarakat Desa Matang Gleum.

\section{DAFTAR PUSTAKA}

Ahyuna MD, Hamzah, Najib M. 2013. Pemanfaatan internet sebagai media promosi pemasaran produk lokal oleh kalangan usaha di kota Makassar. Jurnal Komunikasi KAREBA. 2(1): 30-40.

BPS kabupaten Aceh Timur. 2019. Kabupaten Aceh Timur Dalam Angka 2018. Aceh Timur (ID): Badan Pusat Statistik Kabupaten Aceh Timur.

Hadiyanti P. 2008. Strategi pemberdayaan masyarakat melalui program keterampilan produktif di PKBM Rawasari, Jakarta Timur. Perspektif Ilmu Pendidikan. 17: 90-99. https://doi.org/10.21009/PIP.171.10

Mujiman H. 2007. Manajemen Pelatihan Berbasis Belajar Mandiri. Cetakan II. Yogyakarta (ID): Pustaka Pelajar.

Poespo G. 2005. Pemilihan Bahan Tekstil. Yogyakarta (ID): Kanisius.

Rai IW. 2013. Andragogi Dan Belajar Mandiri dalam Pemberdayaan Masyarakat. Majalah Aplikasi Ipteks Ngayah. 4(1): 1-7. 
Soehersono H. 2010. Desain Bordir Inspirasi Motif Tradisional Jepang. Jakarta (ID): PT. Gramedia Pustaka Utama.

Suwardi AB, Baihaqi, Saumi F. 2018. Inovasi Produk Kerajinan Limbah Kelapa Sawit Menggunakan Teknologi Ramah Lingkungan. Agrokreatif Jurnal Ilmiah Pengabdian kepada Masyarakat. 4(1): 22-30. https://doi.org/ 10.29244/agrokreatif.4.1.22-30

Taib G, Roswita R. 2018. Analisis Prospek dan Kendala Pengembangan Produk Industri Pangan Lokal di Sumatera Barat. Jurnal Teknologi Pertanian Andalas. 22(1): 96-101. https://doi.org/10.25077/jtpa.22.1.96101.2018
Tyas AAWP. 2011. Pentingnya Keselamatan dan Kesehatan Kerja dalam Meningkatkan Produktivitas Kerja Karyawan. Forum Ilmiah. 8(3): 217-223.

[UNDP] United Nations Development Programme. 2012. Modul Pengurangan Risiko Bencana Berbasis Komunitas. Jakarta (ID): United Nations Development Programme and Government of Indonesia.

Unonongo W, Warouw D, Tulung L. 2015. Fungsi promosi dalam meningkatkan daya beli gadget Samsung di Kota Manado. Acta Diurna. 4 (5): 1-12. 